\title{
Development of Single Tubing-Type Canister for Cryo- Storage of Bull Semen and Their Effect on Sperm Motility and Viability
}

\author{
Mohd Iswadi Ismail ${ }^{1,3 *}$, Khairul Osman ${ }^{2}$, Siti Fatimah Ibrahim ${ }^{1}$, Farah Hanan Fatihah \\ Jaafar $^{1}$, Nur Azianie Abd Ghani ${ }^{1}$, Fazly Ann Zainalabidin ${ }^{3}$ and Abas Mazni Othman ${ }^{4}$ \\ ${ }^{I}$ Department of Physiology; The National University of Malaysia; Kuala Lumpur - Malaysia. ${ }^{2}$ Forensic Science \\ Programme; Faculty of Health Sciences; The National University of Malaysia; Kuala Lumpur - Malaysia. \\ ${ }^{3}$ Veterinary Research Institute; Department of Veterinary Services; Ipoh, Perak - Malaysia. ${ }^{4}$ Malaysian Agricultural \\ Research and Development Institute; 43400 Serdang - Selangor - Malaysia
}

\begin{abstract}
The objective of this study was to evaluate the potential of using single tubing-type canister on sperm quality. Semen was collected from the Bali cattle bull by electroejaculation technique and was cryopreserved in liquid nitrogen using slow freezing cryopreservation method. Two type of canister volume was used in this study; commercial canister $\left(342.25 \pi \times 278 \mathrm{~mm}^{2}\right)$ and single tubing-type canister $\left(4 \pi \times 90 \mathrm{~mm}^{2}\right)$. Makler counting chamber and computer assisted sperm analyzer (CASA) were used to evaluate the sperm motility and viability of post-thaw sperm. Results showed that the bull sperm motility and viability at the bottom of tubing-type canister was statistically higher and significant as compared to the commercial canister ( $p<0.05)$. Significant changes were found in sperm kinetics (VCL, VAP, VSL) of tubing-type canister compared to commercial canister. No significant changes in the motility and viability of the bull sperm at the top of tubing-type canister and commercial canister. There were no significant changes in sperm progression (LIN, WOB, PROG) in both the canisters. Developed tubing-type canister in this study showed potential as an alternative to be used in bull sperm cryo-storage.
\end{abstract}

Key words: Cryopreservation, sperm, canister, motility, viability

\section{INTRODUCTION}

There has been considerable attention on the determination of optimum conditions for cryopreservation process and cryo-storage of semen of domestic species (Curry 2000; Barbas and Mascarenhas 2009). Many benefits have resulted from the process of cryopreservation. The most important benefit of all is the ability to store the sperm for long periods of time and still be able to use a portion of it later. Furthermore, semen cryopreservation offers many advantages to the livestock industry and to the maintaining sperm storage of the threatened and endangered wild species (Fickel et al. 2007). Cryopreservation is a technique that involves a very wide range of temperature changes. However, the biggest obstacle to exploiting cryopreserved semen of many species is that cooling, freezing and thawing, which generally damage sperm membrane structures, causes fewer viable and motile sperm (Hammerstedt et al. 1990).

There are very limited reports on the effect of various canisters dimension on the sperm during the semen cryo-storage and canister volume of $342.25 \pi \times 278 \mathrm{~mm}^{2}$ is commonly used for bull

*Author for correspondence: iswadi@dvs.gov.my 
semen cryo-storage. There are various types of considerable materials for bull semen cryo-storage (e.g., vials, straws, etc). Routinely, either $0.25 \mathrm{~mL}$ or $0.5 \mathrm{~mL}$ straws have been a suitable choice for bull semen cryo-storage (Sansone et al. 2000; Vishwanath and Shannon 2000). In this study, a tubing-type canister was developed with the hypothesis that the sperm motility and viability could be related to the use of suitable canister dimension in cryo-storage.

\section{MATERIALS AND METHODS}

\section{Semen collection}

Fresh semen samples were collected from the Bali cattle bulls using electroejaculation technique by a trained veterinarian. Makler counting chamber (Sefi-Medical Instruments Ltd) was used to determine the sperm concentration. All the samples were added to a Bioxcell ${ }^{\circledR}$ medium (IMV Technologies, France) before the cryopresevation process. Motility and viability of the sperm were determined in post-thawed sample.

\section{Cryopreservation technique}

In this study, slow freezing technique was used. After adding with Bioxcell ${ }^{\circledR}$ medium, the samples were then put into a $4^{\circ} \mathrm{C}$ cooling cabinet for $4 \mathrm{~h}$, and then sucked into the $0.25 \mathrm{~mL}$ cryo-straw using the vacuum pump attached with filling nozzle. For each straw, the final concentration of the sperm was set at $25 \times 10^{6}$ sperm $/ \mathrm{mL}$. After keeping the straws above the liquid nitrogen vapor (-60 to $120^{\circ} \mathrm{C}$ ) for nine minutes, they were then plunged and stored in liquid nitrogen $\left(-196^{\circ} \mathrm{C}\right)$ for $24 \mathrm{~h}$ before the motility and viability assessment.

\section{Semen storage}

The straws were stored in two types of canister; commercial canister $\left(342.25 \pi \times 278 \mathrm{~mm}^{2}\right)$ and custom-made tubing-type canister $\left(4 \pi \times 90 \mathrm{~mm}^{2}\right)$ (Fig. 1). The depth of liquid nitrogen tank used was between 320 to $350 \mathrm{~mm}$. The level of the liquid nitrogen on the cylinder was fill and maintained as minimum as $50 \mathrm{~mm}$ above the top of the canister during the storage period. A bundle of straws was stored in commercial canister and one straw per tubing-type canister.

Total of twenty-four $0.25 \mathrm{~mL}$ straws were used; eight straws in the commercial canister, eight in upper tubing-type canister and eight in the bottom of tubing-type canister.

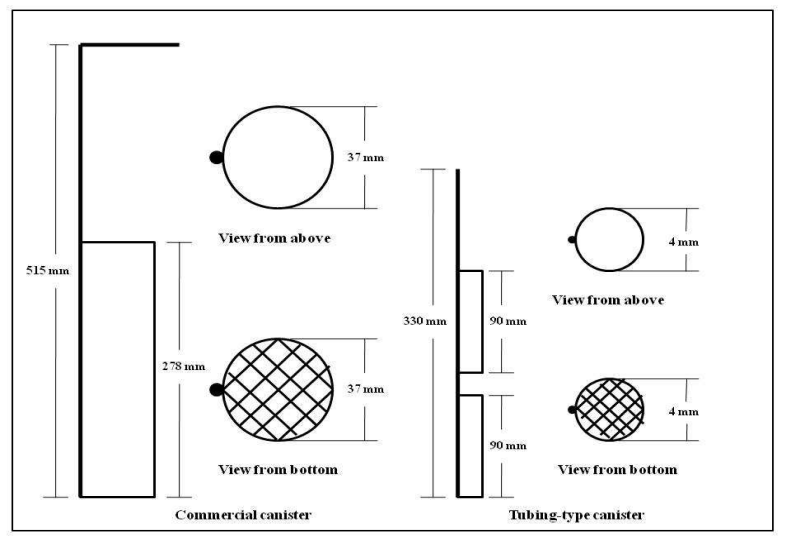

Figure 1 - Comparison of commercial and tubing-type dimension and volume of cryo-storage canister. Commercial canister tube was measured with $37 \mathrm{~mm}$ in diameter and 278 $\mathrm{mm}$ height, while tubing-type canister, 4 $\mathrm{mm}$ in diameter and $90 \mathrm{~mm}$ height. The volume of commercial canister is $342.25 \pi \mathrm{x}$ $278 \mathrm{~mm}^{2}$, whereas the tubing-type canister is $4 \pi x$.

\section{Sperm motility assessment}

Sperm motility was graded from a to d, according to the World Health Organization (WHO 1999) Manual criteria as follows: a for fast progressive motility; b for slow progressive motility; $\mathrm{c}$ for non-progressive sperm; $d$ for immotile sperm. A part of the semen was analyzed by computer assisted sperm analysis (CASA) for sperm velocity and progression assessment.

\section{Statistical analysis}

Data were analyzed using SPSS unpaired t-test at significant level, $\mathrm{p}<0.05$. All the values are shown as means \pm SEM.

\section{RESULTS AND DISCUSSIONS}

A custom-made tubing-type canister was designed, which fitted enough the $0.25 \mathrm{~mL}$ cryo-straw for each tube. This canister was $4.0 \mathrm{~mm}$ in diameter and $330 \mathrm{~mm}$ height with two $90 \mathrm{~mm}$ length of tubes on each cane (top and bottom tube). On the other hand, commercial canister was $37 \mathrm{~mm}$ in diameter and $515 \mathrm{~mm}$ height with $278 \mathrm{~mm}$ length of bucket. The volume of tubing-type canister was $4 \pi \times 90 \mathrm{~mm}^{2}$, which was less when compared to the volume of commercial canister $(342.25 \pi \times 278$ $\mathrm{mm}^{2}$ ).

Fast progressive, slow progressive, nonprogressive and immotile sperm was higher in the 
commercial canister as compared to the tubingtype canister (Fig. 2). Results in this study showed that post-thawed sperm motility were $21.50 \pm 3.32 \%$ (commercial canister), $12.41 \pm 2.86 \%$ (top tubing-type canister) and $7.63 \pm 3.75 \%$ (bottom tubing-type canister). The sperm viability was $28.00 \pm 6.27 \%$ (commercial canister), $26.14 \pm 5.36 \%$ (top tubing-type canister) and $15.75 \pm 4.69 \%$ (bottom tubing-type canister). However, there were no significant changes in all the motility class (a-d) and viability between the commercial and tubing-type (top and bottom) canister (Fig. 3).

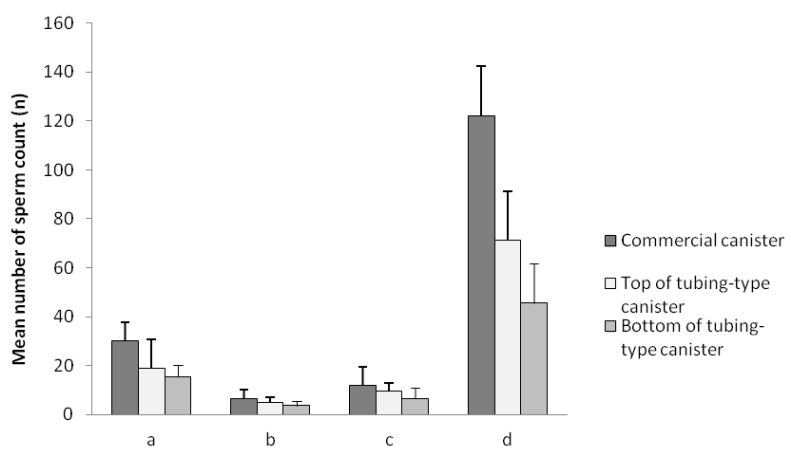

Figure 2 - Comparison of post-thawed sperm grade (a; fast progressive motility, b; slow progressive motility, c; non-progressive sperm, $d$; immotile sperm) in commercial and tubing-type canister.

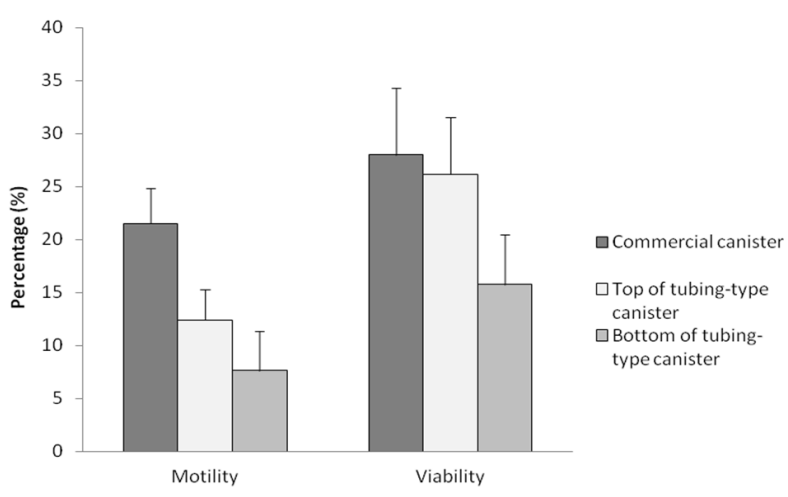

Figure 3 - Comparison of post-thawed sperm motility and viability in commercial and tubing-type canister.

Results by CASA analysis showed that the sperm velocity in the commercial canister were $598.29 \pm 51.4 \mu \mathrm{m} / \mathrm{sec}$ (VCL), $326.03 \pm 30.2 \mu \mathrm{m} / \mathrm{sec}$ (VAP) and $260.39 \pm 24.52 \mu \mathrm{m} / \mathrm{sec}$ (VSL), which in the top tubing-type canister were $850.85 \pm 62.64$ $\mu \mathrm{m} / \mathrm{sec}$ (VCL), $473.66 \pm 40.69 \mu \mathrm{m} / \mathrm{sec}$ (VAP), $373.19 \pm 33.10 \mu \mathrm{m} / \mathrm{sec}$ (VSL) and in bottom tubingtype canister were $625.08 \pm 42.78 \mu \mathrm{m} / \mathrm{sec}$ (VCL),
$359.34 \pm 21.04 \mu \mathrm{m} / \mathrm{sec}$ (VAP) and $283.57 \pm 17.14$ $\mu \mathrm{m} / \mathrm{sec}$ (VSL). Significantly higher $(\mathrm{p}<0.05)$ sperm velocity (VCL, VAP, VSL) was recorded in the top tubing-type canister compared to the commercial and bottom of tubing-type canister (Fig. 4). Results of sperm progression in the commercial canister were $0.82 \pm 0.01 \%$ (LIN), $0.56 \pm 0.02 \%$ (WOB) and $4.09 \pm 0.12 \%$ (PROG), which in the top tubing-type canister were $0.79 \pm 0.01 \% \quad$ (LIN), $\quad 0.57 \pm 0.02 \% \quad$ (WOB), $4.04 \pm 0.12 \%$ (PROG) and in bottom tubing-type canister were $0.80 \pm 0.01 \%$ (LIN), $0.58 \pm 0.01 \%$ (WOB) and $3.82 \pm 0.08 \%$ (PROG). There were no significant changes in sperm progression (LIN, WOB, PROG) between the commercial and tubing-type (top and bottom) canister (Fig. 5).

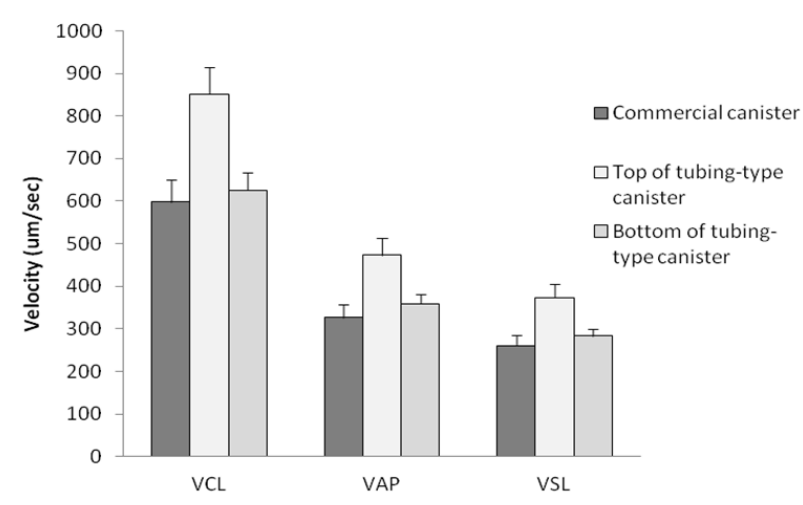

Figure 4 - Sperm velocity (VCL; curvilinear velocity, VAP; averaged path velocity, VSL; straightline velocity) of post-thawed sperm in commercial and tubing-type canister by CASA analysis.

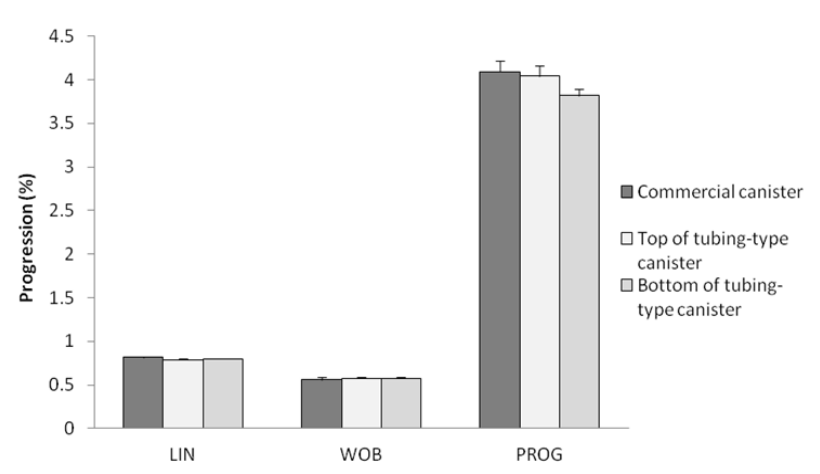

Figure 5 - Sperm progression (LIN; linearity, WOB; wobble, PROG; progression) of post-thawed sperm in commercial and tubing-type canister by CASA analysis.

The temperature of storage is an important consideration for cryo-storage the semen. Gandini 
et al. (2007) reported freezing and cryo-storage of semen as being developed for most livestock species. The use of freezing and cryopreservation techniques for semen storage is tremendously improved, mostly with an aim for genetic conservation of livestock breed population. Various techniques and processes have been used for semen storage in long period of time such as storage at $5^{\circ} \mathrm{C}$ (Bartlett and Van Demark 1962), storage in deep freezer $\left(-40\right.$ and $-80^{\circ} \mathrm{C}$ ) (Polge and Rowson 1952), and cryo-storage at ultra-low temperature $\left(-196^{\circ} \mathrm{C}\right)$ (Fickel et al. 2007). The efficiency and utilization of stored semen could be significantly increased if the effects of freezing and cryopreservation can be overcome. On the other hand, with more advanced cryogenic vessels, it was found possible to maintain the sperm in a frozen state for a very long period. The discovery of glycerol as an effective cryoprotective agent introduced a completely new system of semen storage and a method commonly used following the example set by Polge et al. (1949). Since then, various commercial cryoprotective agents such as Triladyl ${ }^{\circledR}$, Biladyl ${ }^{\circledR}$, Bioxcell ${ }^{\circledR}$ and Andromed $\AA$ have been developed and used for bull semen cryopreservation (Janett et al. 2005; Muino et al. 2007). Bioxcell® was widely used and reported suitable in cryopreservation of domestic bulls and was attributed to the higher concentrations of glutathione, which protected the sperm against oxidative stress and reactive oxygen species (Stradaioli et al. 2007). The level of glutathione in Bioxcell@ was reported sufficient enough to protect the sperm from oxidative stress during freeze-thawing process. Bioxcell ${ }^{\circledR}$ medium also provides nutrients and contains cryoprotectant agent to extend the longevity of the sperm during the cryopreservation process. Based on study by Stradaioli et al. (2007), Bioxcell® was selected and used as cryprotective agent in this study.

Eriksson (2000) reported the technique of freezing semen in 0.25 or $0.5 \mathrm{~mL}$ straws in liquid nitrogen, which has been universally used. This technology is well-established and all the equipment required for filling the semen in straws and racking them up for freezing are readily available. Although there have been considerable studies in determining the optimum cooling rates and adapting the cooling curves for individual bulls, there has been very little progress in the practical sense. Nowadays, semen storage organisational continues to use commercially available canister where the straws containing semen are subjected to cryo-stored in liquid nitrogen. The advantage of the commercial canister is that all the straws in any given freezing cycle are subjected to cryopreserve in large quantity of straws, because the straws are placed in one big bucket of canister. However, the repeatability of movement of the whole straws in the canister to pick up the wanted straw for thawing process affects the sperm due to the changes of the temperature. As an alternative, the development of single-tubing type canister could minimise or prevent the effect of the temperature with only the wanted straw being picked up without disrupting other straws.

Foote (1984) reported the optimal conditions for freezing of bull semen, which led to considerable improvement of sperm survival after freezing and thawing. The results of this study revealed the motility and viability of freezing and thawing sperm in single-tubing type canister as lower compared to the sperm in commercial canister. Results by CASA showed that the sperm kinetics (VCL, VAP and VSL) was significantly higher than the sperm stored in commercial canister. There were statistically no significant changes of sperm progression (LIN, WOB and PROG) in both the canisters; single-tubing type and commercial canister. Result of this study was supported by the earlier findings of Osman et al. (2008), which reported the sperm kinetics highly associated with the DNA damage of the sperm. Using CASA results, they found that VSL, WOB and VCL were important factors in determining the overall condition of a particular sperm with $83.6 \%$ accuracy using the correlation and regression $(\mathrm{C} \& \mathrm{R})$ statistical analysis model. Combination assessment of VSL, WOB and VCL could be used in determining the DNA integrity of the freezethawed sperm.

On the other hand, many studies have reported the physical changes of the sperm associated with freezing and thawing process (Bag et al. 2002; Maldijan et al. 2005; Chaveiro et al. 2006; Leahy and Gadella 2011). The physical changes during the process of freezing and thawing are quite dramatic (Saacke 1982). These were due to the external environment of the semen in the straws during cryo-storage in the canister and the process of freezing and thawing. The physical effects of cooling and freezing on the sperm result in a number of changes in the external environment in terms of water and solute movement. The rate at which water moves out of the cell during this process plays an important role in determining the 
cooling rates, which has to be optimised for cell survival after thawing (Mazur 1977). The effect of freezing on the sperm was due to the stresses associated with freezing, which was primarily due to the changes in the temperature that spermatozoa were subjected during the process of cooling. The injurious effects of the media components and cryoprotectants agent themselves during the process and finally the effects of thawing were other factors.

The general theory is that the rapid thawing of semen is advantageous to prevent the injury during rewarming. Mazur (1984) observed that rapid thawing prevented the possibility of recrystallisation of water molecules, which could be injurious to cell membranes. A potential problem in slow thawing is the osmotic change due to ingress of water during the process, as this is considered to be more damaging than water egress during the freezing (Curry and Watson 1994). Practical considerations regarding the temperature at which semen used in field conditions should be thawed to obtain maximum fertility.

\section{CONCLUSIONS}

Based on the results of this study, it could be concluded that tubing-type canister showed potential compared to the commercial canister and alternatively available to be used in bull sperm cryo-storage. The future direction of research on freezing and cryo-storage semen should be directed towards improvement of freezing protocols to allow a lower number of sperm to be included per straw and tubing unit. For any substantial gain to be made in this direction, future work also needs to concentrate on the diluents composition, repeatable cooling rates to protect the sperm cells during the freezing process and the effect of freezing and thawing at microenvironment of the sperm.

\section{ACKNOWLEDGEMENTS}

We would like to extend our gratitude to the Ministry of Science, Technology and Innovation (MOSTI) for providing research grant (FF 1622009) to support this study.

\section{REFERENCES}

Bag S, Joshi A, Naqvi SMK, Rawat PS, Mittal JP. Effect of freezing temperature, at which straws were plunged into liquid nitrogen, on the post-thaw motility and acrosomal status of ram spermatozoa. Anim Reprod Sci. 2002; 72:175-183.

Barbas JP, Mascarenhas RD. Cryopreservation of domestic animal sperm cells. Cell Tissue Bank. 2009; 10:49-62.

Bartlett FD, Van Demark NL. Effect of temperature on survival of bovine spermatozoa stored in carbonated diluents. J Dairy Sci. 1962; 45:368.

Chaveiro A, Machado L, Frijters A, Engel B, Woelders $\mathrm{H}$. Improvement of parameters of freezing medium and freezing protocol for bull sperm using two osmotic supports. Theriogenology. 2006; 65:18751890.

Curry MR. Cryopreservation of semen from domestic livestock. Rev Reprod. 2000; 5:46-52

Curry MR, Watson PF. Osmotic effects on ram and human sperm membranes in relation to thawing injury. Cryobiology. 1994; 31:39-46.

Eriksson B. Cryopreservation of boar semen: studies on sperm viability in vitro and fertility [ $\mathrm{PhD}$ Thesis]. Uppsala, Sweden: Swedish University of Agricultural Sciences; 2000.

Fickel J, Wagener A, Ludwig A. Semen cryopreservation and the endangered species. Eur $J$ Wildl Res. 2007; 53:81-89.

Foote RH. Buffers and extenders. What do they do? Why are they important? In: Proceedings of the tenth technical conference on artificial insemination and reproduction; 1984 . p. 62-73.

Gandini G, Pizzi F, Stella A, Boettcher PJ. The costs of breed reconstruction from cryopreserved material in mammalian livestock species. Genet Sel Evol. 2007; 39:465-479.

Hammerstedt RH, Graham JK, Nolan JP. Cryopreservation of mammalian sperm: what we ask them to survive. J Androl. 1990; 11:73-88.

Janett F, Keo S, Bollwein H, Hassig M, Thun R. Comparison of Andromed $\AA$, Bioxcell $\AA$ and Triladyl® extender for cryopreservation of bull semen. Schweiz Arch Tierheilk. 2005; 147: 62.

Leahy T, Gadella BM. Sperm surface changes and physiological consequences induced by sperm handling and storage. Reproduction. 2011; 1-56.

Maldijan A, Pizzi F, Gliozzi T, Ceroloni S, Penny P, Noble R. Changes in sperm quality and lipid composition during cryopreservation of boar semen. Theriogenology. 2005; 63:411-421.

Mazur P. The role of intracellular freezing in the death of cells cooled at supraoptimal rates. Cryobiology. $1977 ; 14: 251-272$. 
Mazur P. Freezing of living cells: mechanisms and implications. Am J Physiol. 1984; 247: C125-C142.

Muino R, Fernandez M, Pena AI. Post-thaw survival and longevity of bull spermatozoa frozen with an egg yolk-based or two egg yolk-free extenders after an equilibration period of 18h. Reprod Domest Anim. 2007; 42(3): 305-311.

Osman K, Ibrahim S, Ismail M, Rahman M Abd, Othman A. Data mining: Relationship of sperm kinetics and DNA integrity. Reprod Fertil Dev. 2008; 20: 102-102.

Polge C, Smith AU, Parkes AS. Revival of spermatozoa after vitrification and dehydration at low temperatures. Nature. 1949; 164:666-669.

Polge C, Rowson LEA. Long term storage of bull semen frozen at very low temperatures $\left(-79^{\circ} \mathrm{C}\right)$. Proceeding of the $2^{\text {nd }}$ International Congress on Animal Reproduction (Copenhagen, Denmark); 1952. p. $90-98$.
Saacke R. What happens when a sperm is frozen and thawed, In: Proceedings of the $9^{\text {th }}$ Technical Conference on Artificial Insemination and Reproduction (Milwaukee, Wisconsin, USA); 1982. p. 6-12.

Sansone G, Nastri MJF, Fabbrocini A. Storage of buffalo (Bubalus bubalis) semen. Anim Reprod Sci. 2000; 62:55-76.

Stradaioli G, Noro T, Sylla L, Monaci M. (2007). Decrease in glutathione (GSH) content in bovine sperm after cryopreservation: comparison between two extenders. Theriogenol. 2007; 67:1249-1255.

Vishwanath R, Shannon P. Storage of bovine semen in liquid and frozen state. Anim Reprod Sci. 2000; 62: 23-53.

WHO. Laboratory manual for examination of human semen and semen-cervical mucus interaction. Cambridge University Press, Cambridge, UK; 1999. 